\title{
IMPLEMENTASI PENILAIAN RISIKO \\ DALAM MENUNJANG PENCAPAIAN TUJUAN INSTANSI PENDIDIKAN
}

\author{
Oleh \\ Andian Ari Istiningrum ${ }^{1}$
}

\begin{abstract}
Abstrak
This study is conducted in order to provide information for heads of the education institution to anticipate the risks faced by their institutions. It is necessary for education institutions to do risk assessment since the institutions will always face significant changes that occur due to internal and external changes. The step of risk assessment starts from setting the institution objectives. It is important to divide the institution objectives into more specific one by formulating the objectives for every program. The second step of risk assessment is risk identification. In this step, the risks need to be identified and categorized. In addition, factors that cause the risks should also be analyzed. The last step of risk assessment is analyzing risk. Here, the institution will try to determine the risk status and risk map so that appropriate respons could be taken to handle the risks.
\end{abstract}

\section{Kata kunci: penilaian risiko, perumusan tujuan, identifikasi risiko, analisis risiko}

\section{Pendahuluan}

Instansi pendidikan sebagaimana halnya dengan organisasi dan instansi lainnya pasti akan selalu berhadapan dengan perubahan, baik itu perubahan yang berasal dari dalam maupun dari luar instansi pendidikan. Perubahan pengelolaan pendidikan yang tidak lagi terpusat, perubahan kurikulum hingga berubahnya peraturan pemerintah kesemuanya menuntut perhatian serius dari instansi pendidikan. Perubahan dalam dunia pendidikan terjadi begitu cepat dimana semua perubahan ini diharapkan dapat meningkatkan kualitas pendidikan di Indonesia.

Kualitas pendidikan di Indonesia saat ini banyak sekali menjadi sorotan publik. Banyaknya permasalahan yang membelenggu dunia pendidikan mulai dari pengelolaan aset dan keuangan oleh instansi pendidikan hingga rendahnya mutu lulusan yang dihasilkan dari setiap jenjang sekolah kesemuanya membawa efek negatif bagi dunia pendidikan di Indonesia. Kualitas lulusan sarjana di Indonesia baik itu S1, S2 maupun S3 dipandang jauh lebih rendah kualitasnya daripada lulusan negara tetangga, seperti Malaysia. Selain itu, era globalisasi juga menuntut perhatian lebih dari instansi pendidikan karena instansi pendidikan di Indonesia harus bersaing dengan instansi pendidikan dari negara lain yang bebas membuka cabangnya di Indonesia. Kesemua perubahan ini pada akhirnya akan menjadi risiko yang harus dihadapi oleh instansi pendidikan. Jika risiko ini tidak diolah dengan baik, maka tujuan yang telah ditetapkan oleh setiap instansi pendidikan bisa jadi tidak akan bisa tercapai. Oleh karena itu, penting kiranya bagi setiap instansi pendidikan untuk mengelola risiko sehingga keefektifan tujuan instansi pendidikan bisa diwujudkan.

Penilaian risiko merupakan salah satu unsur dalam Sistem Pengendalian Intern Pemerintah (SPIP) dimana pemerintah telah menetapkan aturan yang jelas mengenai pentingnya SPIP bagi instansi pemerintah dengan dikeluarkannya Peraturan Pemerintah No.

\footnotetext{
${ }^{1}$ Dosen Jurusan Pendidikan Akuntansi - Universitas Negeri Yogyakarta
} 
60 Tahun 2008. Dalam peraturan tersebut, SPIP didefinisikan sebagai proses yang integral pada tindakan dan kegiatan yang dilakukan secara terus menerus oleh pimpinan dan seluruh pegawai untuk memberikan keyakinan memadai atas tercapainya tujuan organisasi melalui kegiatan yang efektif dan efisien, keandalan pelaporan keuangan, pengamanan aset negara dan ketaatan terhadap peraturan perundang-undangan yang diselenggarakan secara menyeluruh pada lingkungan pemerintah pusat dan pemerintah daerah. Instansi pendidikan terutama yang berada dalam lingkup pemerintah hendaknya juga turut serta mematuhi peraturan tersebut dengan mengimplementasikan SPIP dalam lingkup organisasinya.

Berdasarkan definisi SPIP di atas, dapat dilihat bahwa terdapat 4 tujuan yang hendak dicapai oleh SPIP yaitu, (i) efisiensi dan keefektifan pencapaian tujuan negara, (ii) keandalan pelaporan keuangan, (iii) pengamanan aset negara dan (iv) ketaatan terhadap peraturan perundang-undangan. Tujuan tersebut diharapkan dapat dicapai dengan memperhatikan unsur-unsur pembentuk SPIP, yaitu (i) lingkungan pengendalian yang kondusif, (ii) penilaian risiko, (iii) aktivitas pengendalian, (iv) informasi dan komunikasi, dan (v) pemantauan.

Mengingat banyaknya perubahan dan tuntutan yang tinggi akan kualitas pendidikan Indonesia, instansi pendidikan-khususnya yang berada di bawah naungan pemerintah-perlu melakukan penilaian risiko. Hal ini penting untuk dilakukan dengan segera karena penilaian risiko akan membantu instansi pendidikan untuk mengelola risiko tersebut dan meminimalisir dampak yang dapat menghambat pencapaian tujuan instansi pendidikan. Dengan adanya penilaian risiko, efisiensi dan keefektifan dalam memberikan pelayanan akan meningkat sehingga instansi pendidikan dapat memberikan pelayanan yang berkesinambungan kepada stakeholders. Penilaian risiko juga menjadi dasar bagi instansi pendidikan dalam menyusun rencana strategis dan membantu menghindari pemborosan karena seluruh risiko yang mungkin terjadi telah diantisipasi dan dikendalikan oleh instansi pendidikan.

\section{Pembahasan}

\section{A. Risiko dan Proses Penilaian Risiko}

David Mc Namee \& Georges Selim (1998) mendefinisikan risiko sebagai konsep yang digunakan untuk menyatakan ketidakpastian atas kejadian dan atau akibatnya yang dapat berdampak secara material bagi tujuan organisasi. Definisi yang hampir sama disampaikan oleh Bringham (1999) yang menyatakan bahwa risiko adalah bahaya, petaka; kemungkinan menderita rugi atau mengalami kerusakan. Pemerintah Indonesia melalui melalui Bank Indonesia dan Peraturan Pemerintah juga memberikan definisi risiko. Risiko adalah potensi timbulnya suatu kerugian akibat terealisasinya suatu kejadian tertentu yang diperkirakan (Bank Indonesia, 2003). Sedangkan, pengertian risiko berdasarkan Peraturan Pemerintah No. 60 Tahun 2008 yaitu kemungkinan kejadian yang mengancam pencapaian tujuan dan sasaran instansi pemerintah.

Dari pengertian tersebut dapat ditarik kesimpulan bahwa risiko mengandung tiga unsur pembentuk risiko, yaitu (i) kemungkinan kejadian atau peristiwa, (ii) dampak atau konsekuensi (jika terjadi, risiko akan membawa akibat atau konsekuensi, dan (iii) kemungkinan kejadian (risiko masih berupa kemungkinan atau diukur dalam bentuk probabilitas). Ketiga unsur tersebut harus selalu dipenuhi oleh instansi pendidikan ketika akan mengidentifikasi risiko.

Risiko bisa timbul dari sumber internal dan sumber eksternal dari suatu instansi pendidikan. Risiko yang berasal dari sumber eksternal mencakup munculnya peraturan perundang-undangan baru, perkembangan teknologi, bencana alam dan gangguan keamanan. Sementara itu, sumber internal risiko terdiri atas keterbatasan dana operasional, sumber daya manusia yang tidak kompeten, peralatan yang tidak memadai, kebijakan prosedur yang tidak jelas, dan suasana kerja yang tidak kondusif. Selain kedua sumber di atas, risiko juga bisa 
disebabkan oleh faktor lain, misalnya pengeluaran program yang tidak tepat, pelanggaran terhadap pengendalian dana, ketidaktaatan terhadap peraturan perundang-undangan, risiko yang melekat pada sifat misinya atau pada signifikansi (BPKP, 2010).

Peraturan Pemerintah No. 60 Tahun 2008 menegaskan bahwa pimpinan instansi pemerintah wajib melakukan penilaian risiko. Pihak pimpinan instansi pemerintah wajib melakukan penilaian risiko atas faktor-faktor yang mengancam tercapainya tujuan yang telah ditetapkan, baik itu tujuan instansi pendidikan secara keseluruhan maupun tujuan dari setiap kegiatan yang dilakukan oleh instansi pendidikan.

Penilaian resiko adalah metode sistematis dalam melihat aktivitas kerja, memikirkan apa yang dapat menjadi buruk, dan memutuskan kendali yang cocok untuk mencegah terjadinya kerugian, kerusakan, atau cedera di tempat kerja. Penilaian ini harus juga melibatkan pengendalian yang diperlukan untuk menghilangkan, mengurangi,atau meminimalkan resiko (NSH Health Scotland, 2010). Definisi lain tertuang dalam Peraturan Pemerintah No. 60 Tahun 2008 yang menyatakan bahwa penilaian risiko adalah proses yang dilakukan oleh suatu instansi atau organisasi dan merupakan bagian yang integral dari proses pengelolaan risiko dalam pengambilan keputusan risiko dengan melakukan tahap identifikasi rasio, analisis rasio dan evaluasi risiko. Penilaian risiko bertujuan untuk (i) mengidentifikasi dan menguraikan semua risiko-risiko potensial yang berasal baik dari faktor internal maupun faktor eksternal, (ii) memeringkat risiko-risiko yang memerlukan perhatian manajemen instansi dan yang memerlukan penanganan segera atau tidak memerlukan tindakan lebih lanjut, dan (iii) memberikan suatu masukan atau rekomendasi untuk meyakinkan bahwa terdapat risiko-risiko yang menjadi prioritas paling tinggi untuk dikelola dengan efektif (BPKP, 2010).

Penilaian risiko dilakukan terhadap faktor-faktor yang mengancam tercapainya tujuan instansi pendidikan. Oleh karena itu, penetapan tujuan baik itu tujuan instansi maupun tujuan kegiatan merupakan langkap awal dalam melakukan penilaian risiko. Setelah tujuan ditetapkan, instansi pendidikan akan melakukan identifikasi terhadap risiko-risiko yang bisa menghambat pencapaian tujuan tersebut. Identifikasi risiko bisa dilakukan baik terhadap sumber risiko internal, sumber risiko eksternal maupun sumber risiko yang lain. Terhadap setiap risiko yang berhasil diidentifikasi, instansi pendidikan kemudian menganalisis risiko tersebut untuk mengetahui pengaruhnya terhadap pencapaian tujuan. Hasil analisis risiko bisa dijadikan patokan bagi pimpinan instansi pendidikan untuk melakukan pengendalian terhadap risiko tersebut sehingga kemungkinan dan efek terjadinya risiko tersebut dapat diminimalisir.

\section{B. Perumusan Tujuan}

Langkah pertama dalam proses penilaian risiko adalah penetapan tujuan baik itu tujuan strategik dari suatu instansi maupun tujuan operasional. Dalam kaitannya dengan instansi pemerintah, Peraturan Pemerintah No. 60 Tahun 2008 mengatur bahwa tujuan strategik instansi pemerintah harus memuat pernyataan dan arahan yang spesifik, terukur, dapat dicapai, realistis dan terikat waktu. Tujuan strategik ini harus disampaikan kepada seluruh pegawai. Untuk mencapai tujuan tersebut, pimpinan instansi pemerintah wajib menetapkan strategi operasional yang konsisten dan strategi manajemen terintegrasi serta rencana penilaian risiko. Sedangkan, tujuan pada tingkat kegiatan harus ditetapkan dengan mempertimbangkan hal-hal sebagai berikut: (i) berdasarkan pada tujuan dan rencana strategis instansi pemerintah, (ii) saling melengkapi, saling menunjang, dan tidak bertentangan satu dengan lainnya, (iii) relevan dengan seluruh kegiatan utama instansi pemerintahan, (iv) mengandung unsur kriteria pengukuran, (v) didukung sumber daya yang cukup, dan (vi) melibatkan seluruh tingkat pejabat dalam proses penetapannya. 


\section{Identifikasi Risiko}

Identifikasi risiko adalah proses menetepkan apa, dimana, kapan, mengapa dan bagaimana sesuatu dapat terjadi sehingga dapat berdampak negatif terhadap pencapaian tujuan (PP No 60 Tahun 2008). Identifikasi risiko bisa dilakukan secara retrospektif dan prospektif (BPKP, 2010). Instansi pemerintah dapat melakukan identifikasi risiko retrospektif dengan cara mengidentifikasi risiko-risiko yang sebelumnya pernah terjadi dalam instansi tersebut. Karena risiko ini pernah terjadi, risiko tersebut lebih mudah untuk ditetapkan dan dikendalikan oleh instansi pemerintah. Identifikasi risiko secara retrospektif bisa dilakukan dengan mencari informasi dari beberapa sumber, seperti daftar risiko yang dibuat pada periode sebelumnya, dokumen dan laporan yang disimpan perusahaan, laporan audit dan hasil evaluasi lainnya, informasi dari sumber eksternal. Berkebalikan dengan risiko retrospektif, risiko prospektif lebih sulit untuk diidentifikasi karena risiko ini belum pernah dialami suatu instansi. Instansi berusaha untuk membuat prediksi tentang kemungkinankemungkinan buruk yang akan dihadapi oleh instansi baik apakah risiko tersebut dapat dikendalikan maupun sulit dikendalikan. Brainstorming dan analisis SWOT merupakan dua metode penting yang bisa dilakukan untuk mengidentifikasi risiko prospektif.

Salah satu tujuan dari identifikasi risiko adalah untuk menetapkan risiko (BPKP, 2010). Dalam menetapkan risiko, setiap divisi dalam instansi pemerintah harus berusaha untuk mengetahui di mana risiko bisa timbul pada divisi tersebut serta mengidentifikasi penyebab munculnya risiko dan bagaimana risiko tersebut dapat menghambat pencapaian tujuan. BPKP (2010) memberikan panduan beberapa kejadian yang bisa menghambat pencapaian tujuan, yaitu (i) tujuan menjadi lebih lama tercapainya, (ii) tujuan tercapai hanya sebagian $(<100 \%)$, (iii) tujuan tidak tercapai sama sekali, (iv) tujuan tercapai namun dengan biaya yang lebih tinggi, dan (v) tujuan melenceng dari yang telah ditetapkan.

Tujuan kedua dari identifikasi risiko adalah mengkategorisasikan risiko (BPKP, 2010). Risiko dapat dikelompokkan atas dasar (i) jenis risiko, misalkan risiko teknologi, risiko keuangan/ekonomi, risiko sumber daya manusia, risiko kesehatan, risiko politik, risiko hukum, risiko keamanan, (ii) sumber risiko, misalkan risiko eksternal (politik, ekonomi, bencana alam) dan risiko internal (reputasi, keamanan, manajemen, informasi untuk pengambilan keputusan), (iii) penerima risiko, misalkan orang, risiko reputasi, hasil program, bangunan dan aset, lingkungan, pelayanan, (iv) dampak risiko, misalkan risiko rendah, risiko menengah, dan risiko tinggi, (v) kemampuan mengendalikan, misalnya risiko yang sangat terkendali, kurang terkendali, dan tidak/sangat sulit dikendalikan, dan (vi) hirarki risiko, misalnya risiko strategik, risiko program, risiko proyek, dan risiko operasional.

Setelah risiko ditetapkan dan dikelompokkan, identifikasi rasio ini pada akhirnya akan menghasilkan daftar risiko. Daftar risiko merupakan suatu tabel yang berisi sumber risiko dan penyebab terjadinya risiko. Daftar risiko akan menjadi dasar dalam membuat model pernyataan risiko. Ada dua pilihan model pernyataan risiko yang dikembangkan oleh BPKP (2010), yaitu:

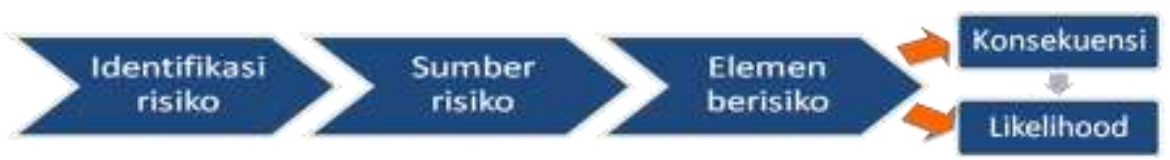

Gambar 1. Model Pernyataan Risiko 1 


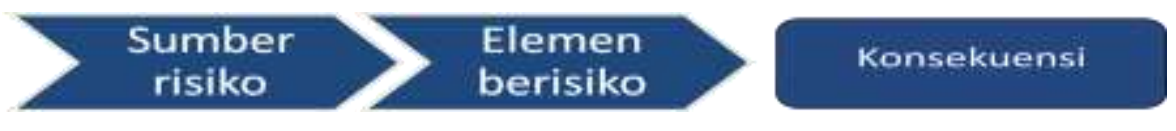

Gambar 2. Model Pernyataan Risiko 2

Untuk mencapai ketiga tujuan di atas, maka proses identifikasi risiko dilakukan dengan melalui tahap-tahap sebagai berikut: (i) penetapan unit risiko, yaitu penetapan organisasi atau unit mana yang akan diidentifikasi risikonya dan tingkatan risikonya, (ii) pemahaman terhadap tupoksi organisasi/unit yang bersangkutan, (iii) pemahaman terhadap aktivitas utama dari organisasi, (iv) reviu atas kriteria risiko yang ada, mencakup tingkat tolerasi risiko, kriteria dampak, kriteria kemungkinan, dan kriteria tingkat keefektifan pengendalian yang sudah ada, (v) pembuatan daftar risiko, dan (vi) pembuatan peta atau profil risiko (BPKP, 2010)

\section{Analisis Risiko}

Peraturan Pemerintah No. 60 Tahun 2008 mendefinisikan analisis risiko sebagai proses penilaian terhadap risiko yang telah teridentifikasi dalam rangka mengestimasi kemungkinan munculnya dan besaran dampaknya untuk menetapkan level atau status risikonya. Status risiko ditentukan berdasarkan kombinasi antara kemungkinan (probabilitas/frekuensi) terjadinya risiko dan dampak (efek) jika risiko terjadi.

BPKP (2010) memberikan panduan bagaimana instansi pemerintah melakukan analisis risiko. Langkah-langkah analisis risiko tersebut adalah sebagai berikut:

1. Menetapkan kemungkinan/probabilitas/frekuensi terjadinya risiko

Tabel 1: Kerangka Pengukuran Probabilitas

\begin{tabular}{|c|c|l|}
\hline \multicolumn{2}{|c|}{ Probabilitas } & \multirow{2}{*}{ Kriteria } \\
\hline Rating & $\%$ & Sangat tidak mungkin/hampir mustahil \\
\hline 1 & $0-10$ & Kecil kemungkinan tapi tidak mustahil \\
\hline 2 & $10-30$ & Kemungkinan terjadi \\
\hline 3 & $30-50$ & Sering terjadi \\
\hline 4 & $50-90$ & Hampir pasti terjadi \\
\hline 5 & $>90$ &
\end{tabular}

Sumber: BPKP, 2010

Tabel 2: Ukuran Kualitatif Kemungkinan/Frekuensi

\begin{tabular}{|c|c|c|c|}
\hline Level & Deskriptor & Contoh Deskripsi Rinci & Frekuensi \\
\hline 1 & Sangat jarang & $\begin{array}{l}\text { Kejadiannya muncul hanya dalam } \\
\text { keadaan tertentu }\end{array}$ & $\begin{array}{l}\text { Kurang dari sekali } \\
\text { dalam } 10 \text { tahun }\end{array}$ \\
\hline 2 & Jarang & $\begin{array}{l}\text { Kejadiannya dapat muncul pada saat } \\
\text { yang sama }\end{array}$ & $\begin{array}{l}\text { Paling sedikit sekali } \\
\text { dalam } 10 \text { tahun }\end{array}$ \\
\hline 3 & Moderat & $\begin{array}{l}\text { Kejadiannya seharusnya muncul } \\
\text { pada saat yang sama }\end{array}$ & $\begin{array}{l}\text { Paling sedikit sekali } \\
\text { dalam } 5 \text { tahun }\end{array}$ \\
\hline 4 & Sering & $\begin{array}{l}\text { Kejadiannya mungkin muncul pada } \\
\text { kebanyakan situasi }\end{array}$ & $\begin{array}{l}\text { Paling sedikit sekali } \\
\text { dalam } 1 \text { tahun }\end{array}$ \\
\hline 5 & $\begin{array}{l}\text { Hampir pasti } \\
\text { /Sangat sering }\end{array}$ & $\begin{array}{l}\text { Kejadiannya diharapkan muncul } \\
\text { pada kebanyakan situasi }\end{array}$ & $\begin{array}{l}\text { Lebih dari satu kali } \\
\text { dalam setahun }\end{array}$ \\
\hline
\end{tabular}

Sumber: BPKP, 2010

2. Menentukan dampak dan besaran dari setiap risiko. 
Tabel 3: Kerangka Pengukuran Dampak

\begin{tabular}{|l|l|l|}
\hline Level & \multicolumn{1}{|c|}{ Rating Dampak } & \multicolumn{1}{|c|}{ Keterangan } \\
\hline 5 & $\begin{array}{l}\text { Sangat tinggi/ } \\
\text { katastropik }\end{array}$ & $\begin{array}{l}\text { Mengancam program dan organisasi serta } \\
\text { stakeholders. Kerugian sangat besar bagi } \\
\text { organisasi dari segi keuangan maupun politis. }\end{array}$ \\
\hline 4 & Besar & $\begin{array}{l}\text { Mengancam fungsi program yang efektif dan } \\
\text { organisasi. Kerugian cukup besar bagi organisasi } \\
\text { dari segi keuangan maupun politis. }\end{array}$ \\
\hline 3 & Menengah/medium & $\begin{array}{l}\text { Mengganggu administrasi program. Kerugian } \\
\text { keuangan dan politis cukup besar. }\end{array}$ \\
\hline 4 & Kecil & $\begin{array}{l}\text { Mengancam efisiensi dan keefektifan beberapa } \\
\text { aspek program. Kerugian kurang material dan } \\
\text { sedikit mempengaruhi stakeholders. }\end{array}$ \\
\hline 5 & $\begin{array}{l}\text { Sangat } \\
\text { signifikan rendah/tidak }\end{array}$ & $\begin{array}{l}\text { Dampaknya dapat ditangani pada tahap kegiatan } \\
\text { rutin. Kerugian kurang material dan tidak } \\
\text { mempengaruhi stakeholders. }\end{array}$ \\
\hline
\end{tabular}

Sumber: BPKP, 2010

3. Menetapkan status risiko dan peta risiko

Formula untuk menghitung status risiko menurut BPKP (2010) adalah sebagai berikut:

Status Risiko = Probabilitas $\mathrm{x}$ Dampak

Berikut adalah tabel untuk menentukan peta risiko.

Tabel 4: Peta Risiko

\begin{tabular}{|c|c|c|c|c|c|c|c|}
\hline \multicolumn{3}{|c|}{ Matriks Analisis Risiko } & \multicolumn{5}{|c|}{ Dampak } \\
\hline & & & 1 & 2 & 3 & 4 & 5 \\
\hline Deskripsi & Prob. & Frek. & $\begin{array}{c}\text { Tidak } \\
\text { Signifikan }\end{array}$ & Kecil & Medium & Besar & $\begin{array}{l}\text { Katas- } \\
\text { tropik }\end{array}$ \\
\hline Hampir pasti & $90 \%$ & 5 & Moderat & Tinggi & Ekstrim & Ekstrim & Ekstrim \\
\hline $\begin{array}{l}\text { Kemungkinan } \\
\text { besar }\end{array}$ & $70 \%$ & 4 & Rendah & Moderat & Tinggi & Ekstrim & Ekstrim \\
\hline Mungkin & $50 \%$ & 3 & Rendah & Moderat & Moderat & Tinggi & Ekstrim \\
\hline $\begin{array}{l}\text { Kemungkinan } \\
\text { kecil }\end{array}$ & $30 \%$ & 2 & $\begin{array}{l}\text { Sangat } \\
\text { rendah }\end{array}$ & Rendah & Moderat & Moderat & Tinggi \\
\hline Sangat jarang & $10 \%$ & 1 & $\begin{array}{l}\text { Sangat } \\
\text { rendah }\end{array}$ & $\begin{array}{l}\text { Sangat } \\
\text { rendah }\end{array}$ & Rendah & Rendah & Moderat \\
\hline
\end{tabular}

Sumber: BPKP, 2010

Tabel 5: Rating Risiko

\begin{tabular}{|l|c|c|}
\hline \multicolumn{1}{|c|}{ Deskripsi } & Level & Level dimulai dari status \\
\hline Ekstrim & 5 & 15 \\
\hline Tinggi & 4 & 10 \\
\hline Moderat & 3 & 5 \\
\hline Rendah & 2 & 3 \\
\hline Sangat rendah & 1 & 1 \\
\hline
\end{tabular}

Sumber: BPKP, 2010. 
4. Menentukan respon terhadap risiko

Tabel 6: Kriteria Respon Risiko

\begin{tabular}{|c|c|c|c|}
\hline Status & \multicolumn{2}{|c|}{ Kriteria untuk Manajemen Risiko } & Yang \\
\hline $1-3$ & Dapat diterima & $\begin{array}{l}\text { Dengan pengendalian yang } \\
\text { cukup }\end{array}$ & Manajer Operasi \\
\hline $4-5$ & Dipantau & $\begin{array}{l}\text { Dengan pengendalian yang } \\
\text { cukup }\end{array}$ & Manajer Operasi \\
\hline $6-9$ & $\begin{array}{l}\text { Diperlukan } \\
\text { pengendalian } \\
\text { manajemen }\end{array}$ & $\begin{array}{l}\text { Dengan pengendalian yang } \\
\text { cukup }\end{array}$ & Manajer Operasi \\
\hline $10-14$ & $\begin{array}{lr}\text { Harus } & \text { menjadi } \\
\text { perhatian } & \text { manajemen } \\
(\text { urgent }) & \\
\end{array}$ & $\begin{array}{l}\text { Dapat diterima hanya } \\
\text { dengan pengendalian yang } \\
\text { sangat baik }\end{array}$ & CEO \\
\hline $15-25$ & Tak dapat diterima & $\begin{array}{l}\text { Dapat diterima hanya } \\
\text { dengan pengendalian yang } \\
\text { sangat baik }\end{array}$ & Komisaris \\
\hline
\end{tabular}

Sumber: BPKP, 2010

5. Memberi informasi kepada pimpinan

Tabel 7: Informasi Pengelolaan Risiko

\begin{tabular}{|c|c|c|}
\hline Status Risiko & Apa yang Terjadi & Apa yang Harus Dilakukan \\
\hline Ekstrim & $\begin{array}{l}\text { - Tujuan dan hasil tidak } \\
\text { tercapai. } \\
\text { - Mengakibatkan kerugian } \\
\text { keuangan yang besar. } \\
\text { - Mengurangi kapabilitas } \\
\text { instansi. } \\
\text { - Reputasi instansi sangat } \\
\text { menurun. }\end{array}$ & $\begin{array}{l}\text { - Pengelolaan bersifat urgen dan } \\
\text { aktif yang melibatkan pimpinan } \\
\text { tingkat tinggi. } \\
\text { - Strategi risiko wajib dilaksanakan } \\
\text { secepatnya. } \\
\text { - Pendekatan yang segera dan tepat } \\
\text { serta pelaporan secara rutin }\end{array}$ \\
\hline Tinggi & 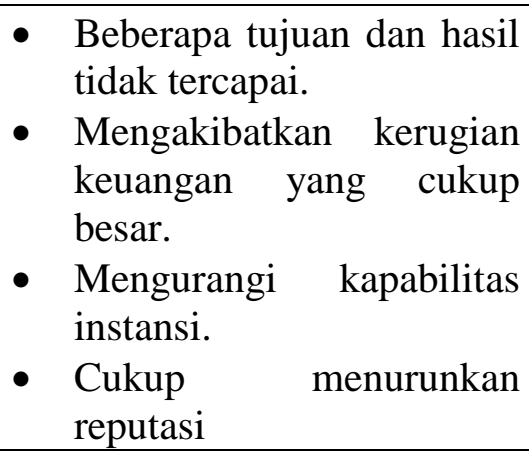 & $\begin{array}{l}\text { - Perlu pengelolaan aktif dan reviu } \\
\text { rutin. } \\
\text { - Strategi harus dilaksanakan } \\
\text { terutama difokuskan pada } \\
\text { pemeliharaan kendali yang sudah } \\
\text { baik. } \\
\text { - Pendekatan yang tepat. }\end{array}$ \\
\hline Medium & $\begin{array}{l}\text { - } \text { Mengganggu kualitas atau } \\
\text { ketepatan waktu dari } \\
\text { tujuan dan hasilnya. } \\
\text { - Mengakibatkan kerugian }\end{array}$ & $\begin{array}{l}\text { - Perlu pengelolaan dan reviu } \\
\text { secara rutin. } \\
\text { - Perlu pengendalian intern yang } \\
\text { efektif dan pemantauan. }\end{array}$ \\
\hline
\end{tabular}




\begin{tabular}{|c|c|c|}
\hline & $\begin{array}{l}\text { keuangan yang dapat } \\
\text { diterima dengan wajar. } \\
\text { - Mengurangi kapabilitas } \\
\text { instansi dalam tingkatan } \\
\text { normal. } \\
\text { - Menurunkan reputasi } \\
\text { dalam tingkat wajar. }\end{array}$ & $\begin{array}{ll}\text { - Strategi } & \text { risiko } \\
\text { dilaksanakan. } & \end{array}$ \\
\hline Rendah & 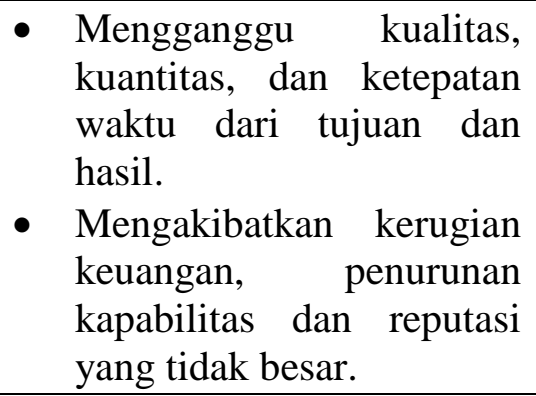 & 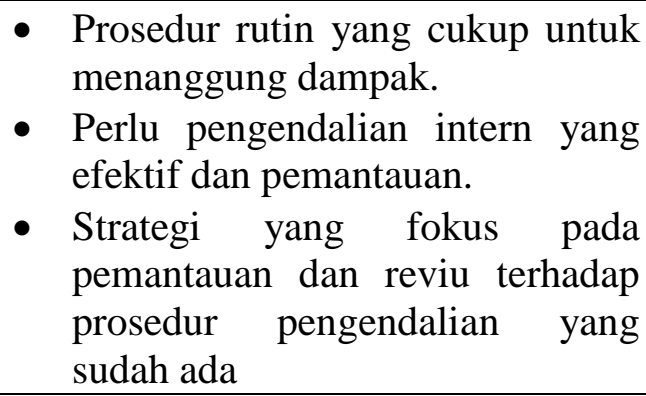 \\
\hline Sangat Rendah & 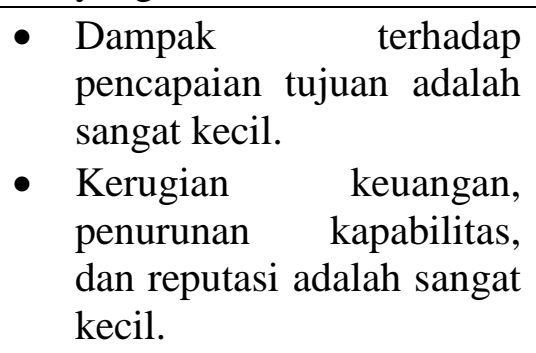 & 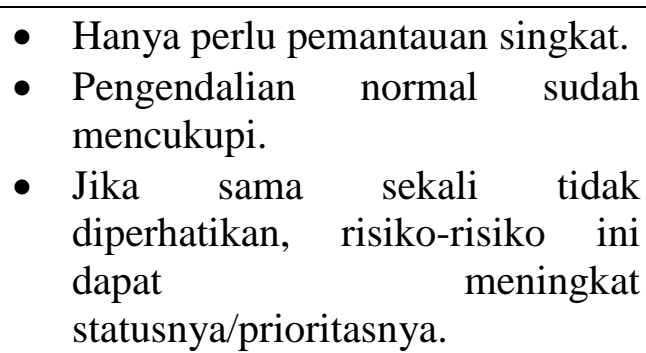 \\
\hline
\end{tabular}

Sumber: BPKP, 2010

\section{E. Implementasi Penilaian Risiko pada Instansi Pendidikan}

Penilaian risiko perlu dilakukan oleh instansi pendidikan mengingat terdapat banyak perubahan terjadi dalam dunia pendidikan dimana dampak dari perubahan perlu dikelola untuk meminimalisir kegagalan pencapaian tujuan yang telah ditetapkan. Berikut ini adalah gambaran bagaimana instansi pendidikan bisa mengimplementasikan penilaian risiko yang tahapannya dimulai dari menetapkan tujuan instansi dan tujuan tingkat kegiatan, identifikasi risiko dan analisis risiko.

\section{1) Merumuskan Tujuan Instansi dan Tujuan Tingkat Kegiatan}

Tujuan instansi pendidikan hendaknya terkait dengan visi dan misi yang telah ditetapkan karena tujuan merupakan implementasi dari visi dan misi. Visi, misi dan tujuan yang akan disajikan dalam makalah ini akan mengadopsi visi dan misi dari salah satu universitas pendidikan di Indonesia, yaitu Universitas Negeri Yogyakarta.

Visi : UNY menjadi universitas kependidikan kelas dunia berlandaskan ketakwaan, kemandirian dan kecendekiaan.

Misi : Mendidik manusia dan masyarakat Indonesia dengan:

1. Menyelenggarakan pendidikan akademik, profesi, dan vokasi dalam bidang kependidikan yang didukung bidang nonkependidikan untuk menghasilkan manusia unggul yang mengutamakan ketaqwaan, kemandirian, dan kecendikian.

2. Menyelenggarakan kegiatan penelitian untuk menemukan, mengembangkan, dan menyebarluaskan ilmu pengetahuan, teknologi, 
seni dan/atau olahraga, yang menyejahterakan individu dan masyarakat, dan mendukung pembangunan daerah dan nasional, serta berkontribusi pada pemecahan masalah global. Menyelenggarakankegiatan pengabdian dan pemberdayaan masyarakat yang mendorong pengembangan potensi manusia, masyarakat, dan alam untuk mewujudkan kesejahteraan masyarakat.

3. Menyelenggarakan tata kelola universitas yang baik, bersih, dan akuntabel dalam pelaksanaan otonomi perguruan tinggi.

Dari keempat misi di atas, hanya satu misi yang akan digunakan sebagai dasar perumusan tujuan yaitu misi ke-2.

\section{Tujuan Instansi}

Terwujudnya penemuan, pengembangan dan penyebarluasan ilmu pengetahuan, teknologi, seni dan/atai olahraga yang mendukung pembangunan daerah dan nasional, serta berkontribusi pada pemecahan masalah global.

\section{Tujuan pada Tingkat Kegiatan}

Tujuan pada tingkat instansi dioperasionalkan dalam suatu kegiatan, dimana salah satu kegiatan yang bisa dilakukan oleh UNY sebagai salah satu instansi pendidikan dengan visi ke depan sebagai universitas kelas dunia adalah menerbitkan jurnal ilmiah berskala internasional. Dengan demikian, tujuan yang hendak dicapai dari kegiatan tersebut adalah terwujudnya jurnal ilmiah berskala internasional.

\section{2) Identifikasi Risiko}

Identifikasi risiko dilakukan dengan melalui tiga tahap penting, yaitu menetapkan risiko, mengkategorisasikan risiko dan membuat daftar risiko.

\section{Menetapkan Risiko}

Direktorat Jenderal Pendidikan Tinggi memberikan panduan kriteria-kriteria yang harus dipenuhi dalam menerbitkan jurnal ilmiah berskala internasional. Kriteria tersebut adalah sebagai berikut:

1. Bahasa yang digunakan adalah bahasa PBB (Inggris, Perancis, Spanyol, Arab, Cina)

2. Pengelolaan naskah sedemikian rupa sehingga naskah yang diterima cepat terbit (rapid review) dan ada keteraturan terbit

3. Jurnal berkualitas (prestisius), bisa dilihat dari daftar penelaah naskahnya dan Editorial Board-nya yaitu pakar di bidangnya dalam dan luar negeri.

4. Dibaca oleh banyak orang di bidangnya, bisa dilihat dari distribusi/peredarannya (circulation).

5. Menjadi acuan bagi banyak peneliti (citation).

6. Tercantum dalam Current Content dan sejenisnya.

7. Artikel yang dimuat berkualitas, bisa dilihat dari kemutakhiran topik dan daftar acuannya.

8. Penyumbang artikel/naskah berasal dari banyak negara

9. Penelaah berasal dari banyak negara yang terkemuka di bidangnya.

10. Menawarkan off-prints/reprints.

11. Terbit teratur sesuai dengan jadwal yang ditentukan.

12. Penerbitan jurnal tidak terkendala oleh dana. 
13. Bukan jurnal Jurusan, Fakultas, Universitas atau Lembaga yang mencerminkan derajat kelokalan. Seyogyanya diterbitkan oleh himpunan profesi.

14. Memberi kesempatan penulis artikel membaca contoh cetak

15. Artikel yang dominan (kalau bisa $>80 \%$ ), berupa artikel orisinil (hasil penelitian), bukan sekadar review atau ulasan.

16. Kadar sumber acuan primer $>80 \%$, derajat kemutakhiran acuan $>80 \%$.

17. Tersedia Indeks di setiap volume.

18. Ketersediaan naskah tidak menjadi masalah ( ITB, 2009).

Dengan melihat pada kriteria-kriteria di atas, maka beberapa kriteria tersebut bisa membawa risiko kegagalan UNY menerbitkan jurnal ilmiah berskala internasional. Tidak semua kriteria di atas menjadi risiko bagi UNY untuk mencapai tujuannya karena untuk bisa disebut sebagai risiko harus memenuhi tiga unsur pembentuk risiko, yaitu

1. Kejadian atau peristiwa

2. Kemungkinan kejadian (risiko masih berupa kemungkinan atau diukur dalam bentuk probabilitas).

3. Dampak atau konsekuensi (jika terjadi, risiko akan membawa akibat atau konsekuensi)

Berikut adalah ilustrasi risiko yang bisa menghambat UNY dalam menerbitkan jurnal internasional.

Tabel 8: Ilustrasi Risiko

\begin{tabular}{|c|c|c|c|c|}
\hline No. & Uraian Risiko & $\begin{array}{l}\text { Kejadian } \\
\text { /Peristiwa }\end{array}$ & $\begin{array}{c}\text { Kemungkinan } \\
\text { Kejadian/Peristiwa }\end{array}$ & $\begin{array}{c}\text { Dampak } \\
\text { /Konsekuensi }\end{array}$ \\
\hline 1 & $\begin{array}{lr}\text { Keterbatasan } & \text { naskah } \\
\text { yang layak untuk } \\
\text { dipublikasikan pada } \\
\text { jurnal berskala } \\
\text { internasional. }\end{array}$ & $\mathrm{Ya}$ & $\begin{array}{l}\text { Ya } \\
\text { Kejadian/peristiwa } \\
\text { ini baru merupakan } \\
\text { kemungkinan } \\
\text { karena bisa saja } \\
\text { pengelola } \\
\text { kemudian } \\
\text { mendapatkan paper } \\
\text { berkualitas tinggi. }\end{array}$ & $\begin{array}{l}\text { Jurnal tidak bisa } \\
\text { terbit teratur atau } \\
\text { terlambat terbit. }\end{array}$ \\
\hline 2 & $\begin{array}{l}\text { Kesulitan dalam } \\
\text { mendapatkan } \\
\text { penelaah (reviewer) } \\
\text { luar negeri. }\end{array}$ & Ya & $\begin{array}{l}\text { Ya } \\
\text { Ada kemungkinan } \\
\text { pengelola akan } \\
\text { menghadapi } \\
\text { peristiwa tersebut } \\
\text { karena masih } \\
\text { terbatasnya jaringan } \\
\text { kerja sama antara } \\
\text { UNY dengan } \\
\text { universitas di luar } \\
\text { negeri. }\end{array}$ & $\begin{array}{lr}\text { Tidak } & \text { memenuhi } \\
\text { kriteria } & \text { penerbitan } \\
\text { jurnal internasional } \\
\text { yang } & \text { ditetapkan } \\
\text { Dikti. } & \end{array}$ \\
\hline 3 & 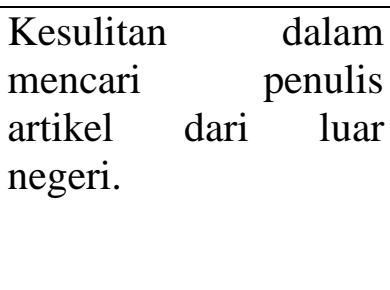 & Ya & $\begin{array}{lr}\text { Ya } & \\
\text { Terbatasnya ruang } \\
\text { lingkup kerja } & \text { sama } \\
\text { dengan } & \text { civitas } \\
\text { akademika } & \text { serta } \\
\text { peneliti luar } & \text { negeri }\end{array}$ & $\begin{array}{lr}\text { Tidak } & \text { memenuhi } \\
\text { kriteria } & \text { penerbitan } \\
\text { jurnal internasional } \\
\text { yang } & \text { ditetapkan } \\
\text { Dikti. } & \end{array}$ \\
\hline
\end{tabular}




\begin{tabular}{|c|c|c|c|c|}
\hline & & & $\begin{array}{l}\text { kemungkinan bisa } \\
\text { menghambat } \\
\text { pengelola dalam } \\
\text { mendapatkan artikel } \\
\text { dari penulis luar } \\
\text { negeri }\end{array}$ & \\
\hline 4 & $\begin{array}{l}\text { Keterbatasan } \\
\text { distribusi/pemasaran } \\
\text { jurnal. }\end{array}$ & Ya & $\begin{array}{l}\text { Ya } \\
\text { Belum dikenalnya } \\
\text { UNY di dunia } \\
\text { internasional } \\
\text { kemungkinan bisa } \\
\text { menjadi faktor } \\
\text { penghambat } \\
\text { distribusi jurnal ke } \\
\text { luar negeri. }\end{array}$ & $\begin{array}{lr}\text { Artikel di jurnal } \\
\text { tidak dibaca dan } \\
\text { tidak } & \text { dikutip } \\
\text { (disitasi) } & \text { oleh } \\
\text { peneliti lain } & \end{array}$ \\
\hline
\end{tabular}

Dari 18 kriteria penerbitan jurnal internasional, hanya 4 faktor yang bisa ditetapkan sebagai risiko. Faktor lain bukan merupakan risiko karena tidak memenuhi salah satu unsur pembentuk risiko sebagaimana dijelaskan dalam uraian di bawah ini.

1. Bahasa yang digunakan yaitu bahasa PBB bukan merupakan risiko karena ada banyak peneliti yang memiliki potensi kemampuan berbahasa asing terutama bahasa Inggris.

2. Keteraturan dan tepat waktu dalam penerbitan merupakan akibat yang timbul karena risiko sedikitnya naskah yang diterima oleh pengelola. Dengan demikian keteraturan dan tepat waktu dalam penerbitn bukan merupakan risiko bagi pengelola melainkan dampak dari risiko keterbatasan naskah.

3. Acuan bagi banyak peneliti bukan merupakan risiko melainkan dampak dari risiko tidak dibacanya jurnal yang diterbitkan pengelola UNY karena keterbatasan distribusi jurnal.

4. Ketersediaan current content, offprint/reprint dan indeks di setiap volume penerbitan bukan merupakan risiko yang dihadapi pengelola karena pengelola memiliki kapabilitas memadai untuk memenuhi kriteria tersebut.

5. Keterbatasan dana merupakan masalah yang dihadapi oleh pengelola jurnal UNY saat ini sehingga hal ini bukan merupakan risiko. Unsur pembentuk risiko yang kedua adalah kemungkinan peristiwa/kejadian terjadi di masa mendatang dan unsur ini tidak dipenuhi sehingga keterbatasan dana tidak tepat jika diidentifikasi sebagai risiko.

6. Jurnal diterbitkan oleh himpunan profesi juga bukan merupakan risiko bagi pengelola karena UNY telah memiliki kerjasama dengan himpunan profesi.

7. Penulis artikel bisa melihat contoh cetak jurnal juga bukan merupakan risiko karena sebagian besar jurnal di UNY selama ini didistribusikan kepada penulis artikel.

\section{Mengkategorisasikan Risiko}

Pengelompokkan risiko dilakukan dengan mengidentifikasi jenis risiko, sumber risiko, penerima risiko, level risiko, pengendalian risiko dan hierarki risiko. Tabel 9 di bawah ini memuat kategorisasi risiko terhadap risiko yang berhasil diidentifikasi dari tahap penetapan risiko.

Tabel 9: Kategorisasi Risiko

\begin{tabular}{|c|c|c|c|c|c|}
\hline No & $\begin{array}{c}\text { Risiko } \\
\text { Teridentifikasi }\end{array}$ & $\begin{array}{l}\text { Jenis } \\
\text { Risiko }\end{array}$ & $\begin{array}{c}\text { Sumber } \\
\text { Risiko }\end{array}$ & $\begin{array}{l}\text { Penerima } \\
\text { Risiko }\end{array}$ & $\begin{array}{l}\text { Hierarki } \\
\text { Risiko }\end{array}$ \\
\hline 1 & $\begin{array}{lr}\text { Keterbatasan } & \text { naskah } \\
\text { yang layak } & \text { untuk }\end{array}$ & $\begin{array}{l}\text { sumber daya } \\
\text { manusia }\end{array}$ & eksternal & $\begin{array}{l}\text { pengelola } \\
\text { reputasi }\end{array}$ & program \\
\hline
\end{tabular}




\begin{tabular}{|c|c|c|c|c|c|}
\hline & $\begin{array}{l}\text { dipublikasikan pada } \\
\text { jurnal berskala } \\
\text { internasional. }\end{array}$ & & & & \\
\hline 2 & $\begin{array}{l}\text { Kesulitan dalam } \\
\text { mendapatkan } \\
\text { penelaah (reviewer) } \\
\text { luar negeri. }\end{array}$ & $\begin{array}{l}\text { sumber daya } \\
\text { manusia }\end{array}$ & eksternal & $\begin{array}{l}\text { pengelola } \\
\text { reputasi }\end{array}$ & program \\
\hline 3 & $\begin{array}{lr}\text { Kesulitan } & \text { dalam } \\
\text { mencari } & \text { penulis } \\
\text { artikel dari luar negeri }\end{array}$ & $\begin{array}{l}\text { sumber daya } \\
\text { manusia }\end{array}$ & eksternal & $\begin{array}{l}\text { pengelola } \\
\text { reputasi }\end{array}$ & program \\
\hline 4 & $\begin{array}{l}\text { Keterbatasan } \\
\text { distribusi/pemasaran } \\
\text { jurnal. }\end{array}$ & $\begin{array}{l}\text { sumber daya } \\
\text { manusia }\end{array}$ & internal & $\begin{array}{l}\text { pengelola } \\
\text { reputasi }\end{array}$ & operasional \\
\hline
\end{tabular}

\section{Membuat Daftar Risiko}

Langkah terakhir dalam proses identifikasi risiko adalah membuat daftar risiko. Untuk keperluan penyusunan daftar risiko, faktor-faktor yang menyebabkan risiko tersebut terjadi harus ditemukan. Tabel di bawah ini memuat contoh daftar risiko dari risiko yang telah diidentifikasi dan dikelompokkan pada langkah sebelumnya:

Tabel 10: Daftar Risiko

\begin{tabular}{|l|l|l|l|}
\hline No. & \multicolumn{2}{|c|}{ Risiko Teridentifikasi } & \multicolumn{1}{c|}{ Faktor Penyebab } \\
\hline 1 & $\begin{array}{l}\text { Keterbatasan naskah yang layak } \\
\text { untuk dipublikasikan pada jurnal } \\
\text { berskala internasional. }\end{array}$ & $\begin{array}{l}\text { Budaya penelitian masih terbatas dimana } \\
\text { penelitian selama ini dilakukan oleh akademisi } \\
\text { untuk memenuhi persyaratan kenaikan pangkat } \\
\text { dan jabatan fungsional. Akibatnya, kualitas } \\
\text { paper yang dihasilkan cenderung rendah dan } \\
\text { belum layak untuk dipublikasikan dalam } \\
\text { lingkup internasional. }\end{array}$ \\
\hline 2 & $\begin{array}{l}\text { Kesulitan dalam mendapatkan } \\
\text { penelaah (reviewer) luar negeri. }\end{array}$ & $\begin{array}{l}\text { Pengelola kurang aktif dalam mengikuti } \\
\text { konferensi/seminar internasional sehingga } \\
\text { jaringan kerja dengan akademisi/peneliti luar } \\
\text { negeri menjadi terbatas. Padahal, } \\
\text { konferensi/seminar internasional merupakan } \\
\text { sarana untuk mendapatkan reviewer secara } \\
\text { langsung. }\end{array}$ \\
\hline 3 & $\begin{array}{l}\text { Kesulitan dalam mencari penulis } \\
\text { artikel dari luar negeri }\end{array}$ & $\begin{array}{l}\text { Pengelola kurang aktif dalam mengikuti } \\
\text { konferensi/seminar internasional sehingga } \\
\text { jaringan kerja dengan akademisi/peneliti luar } \\
\text { negeri menjadi terbatas. Padahal, } \\
\text { konferensi/seminar internasional merupakan } \\
\text { sarana untuk memperoleh jaringan akademisi } \\
\text { dari luar negeri sehingga bisa terjadi saling } \\
\text { tukar artikel untuk dipublikasikan pada jurnal } \\
\text { masing-masing. }\end{array}$ \\
\hline 4 & $\begin{array}{l}\text { Keterbatasan distribusi/pemasaran } \\
\text { jurnal. }\end{array}$ & $\begin{array}{l}\text { Pengelola maupun akademisi UNY belum } \\
\text { banyak yang berpartisipasi dalam acara-acara } \\
\text { lingkup internasional sehingga hal ini } \\
\text { menyebabkan nama UNY masih belum banyak }\end{array}$ \\
\hline
\end{tabular}




\begin{tabular}{|l|l|l|}
\hline & $\begin{array}{l}\text { dikenal secara internasional. Belum dikenalnya } \\
\text { nama UNY mengakibatkan jurnal internasional } \\
\text { yang diterbitkan UNY sulit untuk mendapatkan } \\
\text { pasar pembaca walaupun penerbitan online } \\
\text { dilakukan. }\end{array}$ \\
\hline
\end{tabular}

\section{3) Analisis Risiko}

Langkah terakhir dalam proses penilaian risiko adalah analisis risiko. Analisis risiko dilakukan dengan melalui beberapa tahapan yaitu menetapkan kemungkinan/frekuensi terjadinya risiko, menentukan dampak yang timbul dari setiap risiko, menetapkan status risiko dan peta risiko, menentukan respon terhadap risiko dan member informasi kepada pimpinan. Setiap tahapan dilakukan dengan menggunakan panduan yang telah diberikan oleh BPKP dimana hasil analisis risiko ditunjukkan pada tabel di bawah ini:

Tabel 11: Kemungkinan/Frekuensi Terjadinya Risiko

\begin{tabular}{|c|c|c|}
\hline $\begin{array}{r}\text { Risiko } \\
\end{array}$ & Keterangan & Level \\
\hline $\begin{array}{l}\text { Keterbatasan naskah yang layak } \\
\text { untuk dipublikasikan pada } \\
\text { jurnal berskala internasional }\end{array}$ & $\begin{array}{l}\text { Risiko ini berada dalam kategori jarang terjadi. } \\
\text { UNY memiliki beberapa dosen yang cukup } \\
\text { sering menerbitkan artikel/paper pada jurnal } \\
\text { internasional yang diterbitkan universitas lain } \\
\text { di luar negeri. Jika pengelola kesulitan } \\
\text { mendapatkan artikel, pengelola bisa } \\
\text { menghubungi dosen-dosen tersebut untuk bisa } \\
\text { mengirimkan artikel ke jurnal internasional } \\
\text { UNY. Selain itu, dosen-dosen UNY } \\
\text { diperkirakan juga akan bersemangat dalam } \\
\text { mengirimkan artikel ke jurnal ini karena } \\
\text { penerbitan artikel dalam jurnal sendiri relatif } \\
\text { lebih mudah dibandingkan pada jurnal milik } \\
\text { penerbit lain. }\end{array}$ & 2 \\
\hline $\begin{array}{l}\text { Kesulitan dalam mendapatkan } \\
\text { penelaah (reviewer) luar negeri. }\end{array}$ & $\begin{array}{l}\text { Risiko ini berada dalam kategori mungkin } \\
\text { terjadi. Kendala yang dihadapi jurnal-jurnal } \\
\text { yang diterbitkan UNY untuk mendapatkan } \\
\text { akreditasi nasional adalah sulitnya memperoleh } \\
\text { mitra bestari. Kendala yang sama besar } \\
\text { kemungkinan juga terjadi dalam menerbitkan } \\
\text { jurnal internasional. Akan tetapi, UNY telah } \\
\text { memiliki kerjasama dengan beberapa } \\
\text { universitas di luar negeri sehingga kerjasama } \\
\text { ini bisa digunakan sebagai sarana untuk } \\
\text { mendapatkan reviewer dari luar negeri. }\end{array}$ & 3 \\
\hline $\begin{array}{l}\text { Kesulitan dalam mencari } \\
\text { penulis artikel dari luar negeri }\end{array}$ & $\begin{array}{l}\text { Risiko ini berada dalam kategori mungkin } \\
\text { terjadi. } \\
\text { Beberapa dosen UNY ada yang menempuh } \\
\text { studi lanjut di luar negeri dan mengikuti } \\
\text { seminar internasional walaupun jumlahnya } \\
\text { relatif sedikit jika dibandingkan dengan total } \\
\text { dosen yang dimiliki UNY. Dosen-dosen } \\
\text { tersebut sekiranya bisa mendapatkan artikel } \\
\text { dari jaringan yang telah mereka bentuk selama }\end{array}$ & 3 \\
\hline
\end{tabular}




\begin{tabular}{|l|l|c|}
\hline & mengikuti kuliah/seminar di luar negeri. & \\
\hline Keterbatasan & Risiko ini berada dalam kategori jarang terjadi. & 2 \\
distribusi/pemasaran jurnal. & Pengelola bisa secara kontinyu mengirimkan & \\
jurnal internasional kepada lembaga atau & \\
instansi pendidikan dan penelitian baik dalam & \\
maupun luar negeri sehingga pengelola bisa & \\
& menyusun daftar pelanggan jurnal internasional \\
& UNY. & \\
\hline
\end{tabular}

Tabel 12: Dampak Risiko

\begin{tabular}{|c|c|c|}
\hline Risiko & Keterangan & Level \\
\hline $\begin{array}{l}\text { Keterbatasan naskah yang layak } \\
\text { untuk dipublikasikan pada } \\
\text { jurnal berskala internasional }\end{array}$ & $\begin{array}{l}\text { Dampak risiko berada pada kategori sedang. } \\
\text { Kualitas artikel yang masih belum memenuhi } \\
\text { target jurnal internasional bukan menjadi } \\
\text { hambatan serius dalam menerbitkan jurnal } \\
\text { untuk penerbitan awal. Yang terpenting pada } \\
\text { awal pertama penerbitan bukan terletak pada } \\
\text { kualitas artikel melainkan pada kontinuitas } \\
\text { penerbitan. Setelah kontinuitas terjaga, maka } \\
\text { untuk lebih meningkatkan status akreditasi } \\
\text { internasional, kualitas artikel ditingkatkan. }\end{array}$ & 3 \\
\hline $\begin{array}{l}\text { Kesulitan dalam mendapatkan } \\
\text { penelaah (reviewer) luar negeri. }\end{array}$ & $\begin{array}{l}\text { Dampak risiko berada pada kategori besar. } \\
\text { Reviewer luar negeri merupakan kriteria } \\
\text { penting dalam menerbitkan jurnal berskala } \\
\text { internasional sehingga dengan tidak } \\
\text { terpenuhinya kriteria ini bisa mengakibatkan } \\
\text { jurnal internasional gagal diterbitkan. }\end{array}$ & 4 \\
\hline $\begin{array}{l}\text { Kesulitan dalam mencari } \\
\text { penulis artikel dari luar negeri }\end{array}$ & $\begin{array}{l}\text { Dampak risiko berada pada kategori sedang. } \\
\text { Penulis luar negeri memang merupakan kriteria } \\
\text { penerbitan jurnal internasional yang } \\
\text { memberatkan pengelola pada awal penerbitan. } \\
\text { Akan tetapi, hal ini tidak menghambat } \\
\text { pengelola untuk menerbitkan jurnal } \\
\text { internasional karena pengelola di awal } \\
\text { penerbitan bisa meminta artikel dengan } \\
\text { komposisi sebagian besar dari dalam negeri. } \\
\text { Segera setelah kontinuitas penerbitan terjaga } \\
\text { dan jurnal sudah mulai dikenal, komposisi } \\
\text { penulis dari luar negeri diharapkan dapat } \\
\text { meningkat secara bertahap. }\end{array}$ & 3 \\
\hline $\begin{array}{l}\text { Keterbatasan } \\
\text { distribusi/pemasaran jurnal. }\end{array}$ & $\begin{array}{l}\text { Dampak risiko berada pada kategori kecil. } \\
\text { Dampak dari risiko ini kurang begitu signifikan } \\
\text { dan tidak menghambat penerbitan jurnal karena } \\
\text { pengelola bisa mempelajari bagaimana strategi } \\
\text { pemasaran jurnal sebaiknya dilakukan untuk } \\
\text { mendapatkan pasar pembaca dan pelanggan } \\
\text { jurnal. }\end{array}$ & 2 \\
\hline
\end{tabular}

Tabel 13: Status Risiko dan Respon Risiko

\begin{tabular}{|l|c|c|c|c|} 
Risiko & Frekuensi & Dampak & Status dan & Respon Risiko \\
\hline
\end{tabular}




\begin{tabular}{|l|c|c|c|l|}
\hline $\begin{array}{l}\text { Keterbatasan naskah } \\
\text { yang layak untuk } \\
\text { dipublikasikan pada } \\
\text { jurnal berskala } \\
\text { internasional. }\end{array}$ & $\begin{array}{c}\text { Jarang } \\
\text { Terjadi }\end{array}$ & Sedang & Moderat & $\begin{array}{l}\text { Dapat diterima hanya } \\
\text { dengan pengendalian } \\
\text { yang cukup. }\end{array}$ \\
\hline $\begin{array}{l}\text { Kesulitan dalam } \\
\text { mendapatkan penelaah } \\
\text { (reviewer) luar negeri. }\end{array}$ & $\begin{array}{c}\text { Mungkin } \\
\text { Terjadi }\end{array}$ & Besar & Tinggi & $\begin{array}{l}\text { Dapat diterima } \\
\text { dengan pengendalian } \\
\text { yang sangat baik. }\end{array}$ \\
\hline $\begin{array}{l}\text { Kesulitan dalam } \\
\text { mencari penulis artikel } \\
\text { dari luar negeri }\end{array}$ & $\begin{array}{c}\text { Mungkin } \\
\text { Terjadi }\end{array}$ & Sedang & Moderat & $\begin{array}{l}\text { Dapat diterima } \\
\text { dengan pengendalian } \\
\text { yang cukup. }\end{array}$ \\
\hline $\begin{array}{l}\text { Keterbatasan } \\
\text { distribusi/pemasaran } \\
\text { jurnal. }\end{array}$ & $\begin{array}{l}\text { Jarang } \\
\text { Terjadi }\end{array}$ & Kecil & Rendah & $\begin{array}{l}\text { Dapat } \\
\text { dengan pengendalian } \\
\text { yang cukup }\end{array}$ \\
\hline
\end{tabular}

Tabel 14: Informasi kepada Pimpinan

\begin{tabular}{|c|c|c|}
\hline Risiko & $\begin{array}{c}\text { Pihak yang Bertanggung } \\
\text { Jawab }\end{array}$ & Informasi \\
\hline $\begin{array}{l}\text { Keterbatasan naskah yang } \\
\text { layak untuk dipublikasikan } \\
\text { pada jurnal berskala } \\
\text { internasional. }\end{array}$ & Pimpinan Jurnal & $\begin{array}{l}\text { Pimpinan jurnal perlu } \\
\text { melakukan pemantauan } \\
\text { terhadap risiko yang } \\
\text { timbul }\end{array}$ \\
\hline $\begin{array}{lr}\text { Kesulitan } & \text { dalam } \\
\text { mendapatkan } & \text { penelaah } \\
\text { (reviewer) luar negeri. }\end{array}$ & Pimpinan Universitas & $\begin{array}{l}\text { Pimpinan universitas } \\
\text { perlu memberi perhatian } \\
\text { serius terhadap risiko } \\
\text { yang terjadi. }\end{array}$ \\
\hline $\begin{array}{l}\text { Kesulitan dalam mencari } \\
\text { penulis artikel dari luar negeri }\end{array}$ & Pimpinan Jurnal & $\begin{array}{l}\text { Pimpinan jurnal perlu } \\
\text { melakukan pengendalian } \\
\text { manajemen terhadap } \\
\text { risiko yang terjadi. }\end{array}$ \\
\hline $\begin{array}{l}\text { Keterbatasan } \\
\text { distribusi/pemasaran jurnal. }\end{array}$ & Pimpinan Jurnal & $\begin{array}{l}\text { Pimpinan jurnal perlu } \\
\text { melakukan pemantauan } \\
\text { terhadap risiko yang } \\
\text { timbul }\end{array}$ \\
\hline
\end{tabular}

Keseluruhan tabel tersebut pada akhirnya akan memberikan informasi kepada pimpinan baik itu pimpinan jurnal maupun universitas mengenai risiko yang dihadapi dalam rangka menerbitkan jurnal internasional dan apa yang harus dilakukan oleh kedua pimpinan tersebut untuk mengatasi risiko yang terjadi. Pimpinan jurnal hendaknya perlu melakukan pengelolaan, pengendalian dan pemantauan terhadap operasional penerbitan jurnal. Sedangkan, pimpinan universitas perlu melakukan merumuskan strategi yang ditujukan untuk meningkatkan kualitas penelitian dan penerbitan dengan memberikan dukungan insentif yang memadai. Selain itu, pimpinan universitas juga sekiranya bisa merumuskan pendekatan yang tepat untuk memperluas jaringan kerjasama dengan lembaga/institusi pendidikan di luar negeri. 


\section{Kesimpulan}

Instansi pendidikan sebagaimana instansi yang lain akan dihadapkan pada risiko dimana risiko ini menghambat instansi pendidikan dalam mencapai tujuan yang telah ditetapkan. Oleh karena itu, penting kiranya bagi instansi pendidikan untuk melakukan penilaian risiko. Penilaian risiko diawali dengan proses perumusan tujuan baik itu tujuan instansi maupun tujuan kegiatan. Setelah tujuan dirumuskan, mulailah dilakukan proses pengidentifikasian terhadap risiko serta analisis risiko. Keseluruhan langkah tersebut pada akhirnya akan memberi informasi kepada pimpinan baik itu pimpinan instansi maupun pimpinan kegiatan untuk melakukan pendekatan yang tepat guna meminimalisir dampak dari risiko.

\section{Daftar Pustaka}

Badan Pengawasan Keuangan dan Pembangunan, 2010, Penilaian Risiko, Pusat Pendidikan dan Pelatihan Pengawasan, Jakarta.

Bank Indonesia, 2003, Peraturan Bank Indonesia No 5/8/PBI/2003, tentang Penerapan Manajemen Risiko Bagi Bank, Bank Indonesia, Jakarta

Bringham, EF., \& Gapenski, LC., Daves, PR., 1999, Intermediate Financial Management, The Dryden Press, New York

Institut Teknologi Bandung, 2009, Panduan Bagi Pengelola Jurnal Ilmiah, Lembaga Penelitian dan Pengabdian Kepada Masyarakat, Bandung.

Namee, David Mc, et all, Risk Management: Changing The Internal Auditor's Paradigm, Institute Of Internal Auditors Research Foundation, Altamore, Sping Florida, 1998, hal.186.

NSH Health Scotland. 2010. Risk Assessment. http://www.healthyworkinglives.com/advice/minimising-workplace-risks/riskassessment.aspx\#what. Diakses pada tanggal 11 februari 2012.

Pemerintah Indonesia, 2008, Peraturan Pemerintah Nomor 60 Tahun 2008 tentang Sistem Pengendalian Intern Pemerintah, Biro Peraturan Perundang-undangan Bagian Politik dan Kesejahteraan Rakyat, Jakarta. 